The University of San Francisco

USF Scholarship: a digital repository @ Gleeson Library | Geschke Center

Sport Management

College of Arts and Sciences

2017

\title{
Cricket South Africa's Protea Fire brand
}

Luisa Mazinter

Michael M. Goldman

University of San Francisco, mmgoldman@usfca.edu

Jennifer Lindsey-Renton

Follow this and additional works at: http://repository.usfca.edu/sm

Part of the Sports Management Commons

\section{Recommended Citation}

Luisa Mazinter, Michael M. Goldman, Jennifer Lindsey-Renton, (2017) "Cricket South Africa’s Protea Fire brand", Emerald Emerging Markets Case Studies, Vol. 7 Issue: 1, pp.1-20, https://doi.org/10.1108/EEMCS-05-2016-0081

This Article is brought to you for free and open access by the College of Arts and Sciences at USF Scholarship: a digital repository @ Gleeson Library | Geschke Center. It has been accepted for inclusion in Sport Management by an authorized administrator of USF Scholarship: a digital repository @

Gleeson Library | Geschke Center. For more information, please contact repository@usfca.edu. 


\section{CRICKET SOUTH AFRICA'S PROTEA FIRE BRAND}

It was 24 March 2015 and Marc Jury, the Head of Commercial and Marketing of Cricket South Africa (CSA), and his project team behind the \#ProteaFire brand campaign could hardly bear to watch as the Cricket World Cup semi-final match between the South African Proteas ${ }^{1}$ and the New Zealand Black Caps advanced to the last over ${ }^{2}$. Having never reached the final of a Cricket World Cup before, despite being rated the team to beat several times, the Proteas looked like they were in the driving seat having set a tough target of 298 runs for the New Zealand team to chase. Yet some impressive batting by the Black Caps and missed chances by the South Africans meant that the New Zealand team went into the final over needing an attainable 12 runs.

The tension in the boardroom at CSA heightened further when the Proteas' number one bowler, Dale Steyn, began limping from what appeared to be a calf strain two balls into the over. With just four balls left of the rain-shortened match, New Zealand needed ten runs to win. As Steyn ran in to bowl, the New Zealand batsman, Daniel Vettori, stretched for the ball and sent it to the boundary for four runs, leaving his team with just six runs to get. The next ball saw Vettori miss, yet he sprinted down the pitch for an additional run, leaving the home team with five runs off two balls to win and the New Zealand batsman, Grant Elliott, on strike. As Steyn ran in to bowl the penultimate ball, the entire South Africa held its breath. Jury, who had a deep love for the game of cricket and a strong reputation and track record in the sports business industry, was anxious about the game, as well as the broader \#ProteaFire brand campaign. He wondered how the performance of the Proteas on the field would translate into results for the brand off the field. Had his management team built enough momentum behind \#ProteaFire? Were their plans adaptive and resilient enough to overcome possible on-field disappointments? He leaned in to the cricket broadcast, hoping Steyn would take South Africa to its first Cricket World Cup final.

\section{Cricket in South Africa}

Cricket was a game played in 103 countries using a bat and ball on an oval field, with two teams of eleven players each. By 2011 it was believed to be the world's second most popular sport ${ }^{3}$, after football/soccer, and was expected to generate $\$ 2.5$ billion for the governing International Cricket Council in the eight years from 2016. There were three different formats of cricket (Twenty20, one-day and $\mathrm{Test}^{4}$ ), so depending on the format played a game could last anywhere from three hours to five days. Although the rules and the way the game was played were quite different from baseball, the essential concept of cricket was similar: each team scored runs in successive innings, with the opposing team bowling and fielding. The winning team was the one with the most number of runs after an equal number of innings ${ }^{5}$.

Although the game of cricket grew in South Africa after its introduction to the country in 1808, the Apartheid policies of the government led to South African cricketers being isolated from the rest of the world from 1970 to 1991 . Given the negative connotations from the Apartheid era, the national cricket team's name was changed from the Springboks to the Proteas in the same year ${ }^{6}$, although a similar renaming was decided against for the national rugby team.

\footnotetext{
${ }^{1}$ The Proteas are the South African national cricket team, named after the national flower of South Africa.

${ }^{2}$ An over constitutes the bowling of six balls. There are 50-overs per innings in a one-day World Cup game.

${ }^{3}$ Ridgers, B. (2011). And the silver goes to..., The Economist. Available at: http://www.economist.com/blogs/gametheory/2011/09/rankingsports'-popularity [Accessed 11 April 2015]

${ }^{4}$ Test cricket can last up to 5 days, one-day games have 50 over each, and Twenty 20 games have 20 innings each

5 “An Explanation of Cricket - Basics," Purdue, 2009, https://www.cs.purdue.edu/homes/hosking/cricket/explanation.htm\#basics, accessed April 10,2015

${ }^{6}$ Matloff, J. (1995). What's in a Name? A New S. Africa Alters Its Symbols. The Christian Science Monitor, Available at:

http://www.csmonitor.com/1995/0109/09051.html [Accessed August 7, 2015]
} 


\section{The Protea Fire idea}

In 2010 the South African cricket team were seen to be a talented outfit that was yet to fulfill its potential to be the number one ranked side in the world. The team captain, Graeme Smith, along with some of his senior teammates and team management, were concerned that the Proteas, while successful, were not playing as a cohesive unit. Smith attributed this in part to the fact that the team name had been assigned to them and that no team culture had been handed down through the generations, thanks to the legacy of Apartheid. It was during a conversation held between Smith and the then team psychologist, Jeremy Snape, that the idea for Protea Fire was born. According to Smith "it was time for us to turn our diversity into a strength and to create our own unique identity using the Protea as our unifying symbol"7.

Smith and Snape began researching the Protea flower, discovering that the origin of the name came from the Greek God, Proteus, who could see into the future and could only tell the truth. They also learnt that the flower is extremely resilient, needs fire to regenerate itself, and is very adaptable. These four attributes - truth, resilience, fire and adaptability - were to become the core of the team's values, to which 'fast' and 'Ubuntu' ${ }^{8}$ were added'. Smith and Snape decided to take the team for a three-day strategic getaway, during which time they shared their findings and led exercises which underscored the values and ethos of what the Protea Fire concept meant. ${ }^{10}$

Marc Jury recalled the idea from Smith: "The team really got behind the idea of these core values; there was a discernable shift from the guys playing for a salary cheque and their own individual performances to something more meaningful, which was playing for their country and their fans. The idea of Protea Fire is one that has grown into a legacy; it's become a way of life for the players. When you get picked for the Proteas you don't get a sheet of paper listing the values, it's instilled in you through a way of life, the environment, how the guys operate, and the respect they have for each other." 11

\section{Igniting Protea Fire}

Initially the Protea Fire concept was held closely within the team, who used it to foster a strong sense of team spirit and camaraderie. ${ }^{12}$ The impact it had on the racially and culturally diverse squad was evident in their successes over the years, with the team becoming only the second in history to simultaneously become number one in all three formats of the game in August 2012. ${ }^{13}$

In 2013 Jury heard about Protea Fire for the first time. Although the Proteas team were often ranked as one of the best in the world, they had suffered disappointing knockout round losses in previous World Cup tournaments, and had attracted the unwanted tag of cricket's serial "chokers"14 (see Exhibit 1). Jury had joined CSA in late 2012 after working with SAIL, a sport, sponsorship and entertainment firm that was the existing exclusive commercial agent for CSA. He also had a strong market research background and had the reputation of going to every meeting prepared with facts and figures. Jury approached the team management to ask them if they would present the Protea Fire concept to the Exco, and it was at a

\footnotetext{
${ }^{7}$ CSA. (2014, 9 November). How did ProteaFire start? Available at: https://www.youtube.com/watch?v=yShcIfg69NE [Accessed 10 April 2015]

${ }^{8}$ Ubuntu is an African concept which translates into 'human-ness' or 'humanity toward others'.

${ }^{9}$ Ibid.

${ }^{10}$ Interview with Marc Jury, 31 March 2015

${ }^{11}$ Ibid.

${ }^{12}$ Ibid.

${ }^{13}$ McGlashan, A. (2012, August 28). Amla ton leads SA to third No. 1 spot. Available at: http://www.espncriciinfo.com/england-v-south-africa2012/content/story/579730.html [Accessed 11 April 2015]

${ }^{14}$ Kallis, J. (2015, March 12). Proteas tarred with same brush of failure. Available at http://www.cricket.com.au/news/feature/jacques-kallissouth-africa-cricket-world-cup-chokers-proteas/2015-03-12 [Accessed 11 April 2015]
} 
strategic session in early 2014 that the team agreed that the time was right to share Protea Fire with the country. Lynn Naude, the previous General Manager for sponsorships and events at a leading retail bank, was invited to head up the project team for the campaign from mid-2014. According to Jury, "The campaign's role was to articulate Protea Fire - to give it a vocabulary, feeling and imagery that reflected who the team was and what they stood for. The team also wanted to be actively involved in the campaign and its thinking to ensure that the essence of their team was correctly captured". ${ }^{15}$

"In the past the marketing campaigns came from the marketing, commercial or brand teams, but this was unique - 'inside out' as opposed to 'outside-in'. We realised that if we really got behind it and told the guys' stories, it would add great value to the nation and the fans, as they would get a real understanding of the team. We were fortunate that the Proteas were behind the campaign the whole way. Apart from their 'jobs' as cricketers and the pressure of preparing for the World Cup, they also contributed to the creative process in bringing Protea Fire to life, took part in activations, meet and greets, competitions, signing sessions and launches, as well as fulfilling their sponsor and media obligations. The boys loved the chance to give back to the fans and to say 'It means everything to us to represent you. Thank you for sharing in our joy and our pain'. They made it easy for the fans to know what they were going through as they were open and honest on the various social media platforms and in the various content pieces we created." 16

From the outset the campaign was split up into four phases ${ }^{17}$ :

Table 1: Campaign phases

\begin{tabular}{|l|l|l|l|}
\hline & Phase & Timing & Platforms \\
\hline $\mathbf{1}$ & Establish \#ProteaFire & Oct/Nov 2014 & TV, social media, retail \\
\hline $\mathbf{2}$ & $\begin{array}{l}\text { Integrate Cricket World Cup messaging to } \\
\text { mobilise South Africa, encourage } \\
\text { participation and reward fans }\end{array}$ & $\begin{array}{l}\text { Dec 2014 and } \\
\text { Jan 2015 }\end{array}$ & $\begin{array}{l}\text { TV, radio, social media, } \\
\text { digital, activations, PR } \\
\text { talkability }\end{array}$ \\
\hline $\mathbf{3}$ & $\begin{array}{l}\text { Maintain ongoing support for the team, even } \\
\text { from afar }\end{array}$ & $\begin{array}{l}\text { Feb/Mar 2015 } \\
\text { Driven through Lead SA with } \\
\text { support via social media and } \\
\text { PR talkability }\end{array}$ \\
\hline $\mathbf{4}$ & Thank South Africans for their support & End Mar 2015 & TV, social media, PR \\
\hline
\end{tabular}

Source: Adapted from Final \#ProteaFire Report by Lynn Naude, 28 May 2015

\section{Core objectives}

It was important to the CSA team that they helped people to understand what the Proteas were about and what made the players "tick". Altaaf Kazi, a former journalist and now CSA's Head of Media and Communications, explained that "We really wanted to enable fans to 'get' the life of a Protea; it looks really glamorous but up to ten months of the year they're on the road and they only have each other. We wanted to let the fans get behind the team because it's a team for the country". ${ }^{18}$

The project team also wanted to make sure that young cricketers across the country would have some kind of orientation around \#ProteaFire, so that when they move through the ranks they know what the values, ethos and culture of the Proteas are and can live their professional and private lives according to those. As Kazi saw it, the CSA team's job was to "make sure that when a player comes into the squad he

\footnotetext{
${ }^{15}$ Interview with Marc Jury, 31 March 2015

${ }^{16}$ Interview with Altaaf Kazi, 31 March 2015

${ }^{17}$ Final report by Lynn Naude, 28 May 2015

${ }^{18}$ Interview with Altaaf Kazi, 31 March 2015
} 
knows he'll be welcomed into the environment and that he has a role to play. It mustn't be difficult for him to adjust because \#ProteaFire will have lived in him since he was a junior cricketer". ${ }^{19}$

The first objective of the \#ProteaFire campaign was to position and continue to elevate the national cricket team and build genuine affinity for the Protea brand. The secondary objective was a short-term one - to mobilise South Africans behind the team for the World Cup once the affection for them had developed. ${ }^{20}$ The call to action for this second objective was simple - it asked the South African public to visit cricket.co.za to send a message of support to the Proteas. ${ }^{21}$ Naude outlined the brand message that the project team disseminated during the campaign:

"In the first phase we spoke about 'This is \#ProteaFire' and the qualities and values that the team live by. In the second phase we promoted 'South Africa - you inspire \#ProteaFire', and asked the public to demonstrate their support for the guys. Our role wasn't to create a new concept but to articulate something that already existed. We had to give it a vocabulary, look and feel, while making sure that we constantly checked back with the team, as they had lived in the environment for four years and we wanted to reflect it authentically. It wasn't that there was no love for the team, but it had been forgotten. The team travels so much that in many cases it was 'out of sight, out of mind'. We believed that the public didn't know who they were getting behind, so we first wanted to establish \#ProteaFire by reintroducing the public to the team and sharing their values. The second and third phases of the campaign was to get the public behind the team."22

Kazi was well aware that they were fortunate to have been given the go-ahead to work on this particular campaign. "It was a milestone for CSA to approve the \#ProteaFire campaign, not least because it cost quite a bit of money. Fortunately it proved to be extremely successful and the concept of a team-driven campaign was proven to work." ${ }^{23}$

Jury confirmed, "This was the first time that we properly invested in our property. So often when you look at campaigns around big sports team, they're led by the sponsors who are just leveraging their association with the team, but what stood out for our partners was that we had invested in our own brand and will continue to do so. This is the first time in a long time that we've had potential sponsors knocking on our door - our sponsors have loved being part of the journey and want to continue to be part of it going forward." 24

The Proteas also felt that the campaign re-enforced who they play for; for the first time in many years they felt truly connected to the public and they felt the public were really backing them and they understood how important winning the World Cup was to the country - particularly given the fact that they had fallen short at every previous tournament. ${ }^{25}$

\section{Managing the campaign}

The project team was made up of specialists in branding, logistics, stadium activations, public relations, social media, amplification of social media, radio, TV and content creation. ${ }^{26}$ Naude was conscious that

\footnotetext{
${ }^{19}$ Ibid.

${ }^{20}$ Final report by Sipokazi Sokanyile, 8 June 2015

${ }^{21}$ Interview with Lynn Naude, 31 March 2015

${ }^{22}$ Ibid.

${ }^{23}$ Interview with Altaaf Kazi, 31 March 2015

${ }^{24}$ Interview with Marc Jury, 31 March 2015

${ }^{25}$ Interview with Lynn Naude, 31 March 2015

${ }^{26}$ Ibid.
} 
the project team was big, so everyone agreed upfront that they had to be disciplined and always check each decision against three filters:

"was it authentic, was it focused, and did it drive people to create a message of support? It was a very collaborative approach, which kept everyone honest and accountable; at the weekly meetings people would come with different ideas and even if they passed all the filters, if anyone was unsure about a concept, including $\mathrm{AB}^{27}$, we didn't use it. This meant that we were able to stay focused on what we were trying to achieve; we may have had a great idea but if it deviated from our objectives or if it didn't feel 'real' to the team, even if it might have reached more people, it was discarded." 28

Kazi stressed the importance of the key messaging document that was developed at the outset of the campaign and shared with the large project team and diverse group of outsourced agencies: "We knew what we wanted to achieve so we used the document as a script; it kept everybody aligned so that it didn't matter if we were talking on social media, TV or at a game, we always knew what we would say." 29

\section{Campaign content}

\section{Phase 1 - This is \#ProteaFire}

The primary objective was to establish \#ProteaFire and ensure that post phase 1, fans knew the answer to the question: What is \#ProteaFire? The inclusion of the hashtag across the campaign was also deliberate and resulted in tremendous social media traction around the campaign and its identity. When establishing \#ProteaFire and communicating to fans, it was important to ensure that the communication reflected all formats of the game, regardless of the fact that the format for the Cricket World Cup (CWC) was one-day games. ${ }^{30}$ The campaign was launched at a private function for key stakeholders on 9 October 2014. The public launch took place on the 'Thursday Night Live with Marawa' show on SuperSport ${ }^{31}$ that same evening, which was followed by a media event with members of the Proteas team. The platforms used in Phase 1 were TV, a daily social media content plan and a presence in retail stores. The television communication was led by a strong manifesto piece that established \#ProteaFire, told the story of the Protea and what it means to be a Protea:

Men, what does playing in this shirt mean?

Each and every one of us are where a million kids dream to be

We get to pull on this shirt and wear the badge on our hearts

We get to sing our anthem and play for 60 million fans

like the heroes who came before us.

But what does a Protea have to do with all of that?

It has everything to do with it

No matter how hot the fire burns, the Protea will always survive

It has the will to grow back stronger

To do what needs to be done.

We are Proteas. We are South Africa.

\footnotetext{
${ }^{27}$ AB de Villiers was the captain of the Proteas for the 2015 Cricket World Cup

${ }^{28} \mathrm{Ibid}$.

${ }^{29}$ Interview with Altaaf Kazi, 31 March 2015

${ }^{30}$ Final report by Lynn Naude, 28 May 2015

${ }^{31}$ A provider of pay-television sports coverage across Africa
} 
We find a way boys, we do what it takes

This team never gives up

We're the guys that bat with a broken hand

We take 5 wickets on the flattest deck in the world

Who does that? The Proteas do that boys.

We're the guys that bat for 8 hours in the hottest weather,

to save a Test match

For me boys, that's the Proteas

We bleed, we hurt and we fight together right to the end

That's what makes us who we are boys.

We know who we are and we know who we play for

We are South Africa

To the team - Proteas!

The manifesto piece also launched the campaign vocabulary, including 'We represent you', 'A Protea always survives', 'We are South Africa', 'We play as one' and 'We never give up' (see Exhibit 2). This was supplemented by individual player interview pieces that were flighted on the SuperSport, DSTV ${ }^{32}$ and $\mathrm{SABC}^{33}$ platforms, where players shared with the fans what it meant to them to play for the Proteas.

The imagery created for the campaign was utilized by adidas in various retail stores, as well in the social media content plan that used Facebook, Twitter, YouTube and Instagram to reinforce the characteristics of \#ProteaFire, including a three day focus on each member of the squad. Naude knew that they were creating so much "amazing content" that YouTube was going to be somewhere it could "definitely live", but they had to choose what would work best for the budget and the tools at their disposal so that they could amplify it in the most advantageous way.

"As we had great relationships with the SABC and SuperSport, who support us from a television broadcast point of view, we decided to round out our media coverage by buying online advertising and radio airtime, which was extremely successful. Our social media investment in particular exposed the content to an audience who was eager to consume and engage with it. Included in this were video diaries, the scripts for which were written by the Proteas themselves, which were created during tours to Sri Lanka, Zimbabwe, Australia and New Zealand in 2014. These provided an ongoing opportunity for the public to get to know the team and what happens on tour, which helped the team show they were accessible and gave them a sense of humanity.",34

\section{Phase 2 - South Africa you inspire \#ProteaFire}

Phase 2 coincided with the West Indies summer tour to South Africa in December 2014/January 2015. This was the last series the team played before the CWC, and provided the opportunity for six weeks of high frequency communication across multiple touch points. With the World Cup only consisting of oneday games, the communication in Phase 2 reflected that format of the game. Following the establishment of \#ProteaFire amongst fans, the brand communication was adapted with a strong call to action for the

\footnotetext{
${ }^{32}$ A digital satellite TV service in Africa

${ }^{33}$ The South African Broadcasting Corporation

${ }^{34}$ Final report by Lynn Naude, 28 May 2015
} 
public to support the team and send their messages of support for the CWC. The message centred on 'South Africa you inspire \#ProteaFire'. Two fans stood the chance to be rewarded by travelling to Australia to join the team if their messages were selected by the Proteas team, while fifteen of the finalists for the best messages would each receive a signed thank you shirt from the Proteas for participating in the campaign. ${ }^{35}$

The competition was announced on 4 December 2014 on SABC 3's 'Sport at 10' and immediately started to get traction. The platforms included TV, radio, social media, interviews with players and campaign team members and in stadia experiences. An emotive and strong call to action was implemented, where the team 'spoke' to South Africans and let them know that they took their inspiration from the people of South Africa. The winning messages were selected by the team and the 2 lucky winners were contacted telephonically by Morne Morkel, one of the Protea players. The script that members of the team delivered read:

South Africa, nothing makes me prouder than playing for you. Than walking out to bat or running in to bowl, for you. Playing for this team is a dream come true. Guys, when you wave our flag we see you. When you sing our anthem, we hear you. Your will, is our will. Your fire, is our fire. We want what you want. In fact, we will do whatever it takes to make it happen. Because you, you, you, you and you. Every one of you inspire Protea Fire.

The team made a surprise visit to the home of 11-year old Kieron Adams, a member of the Proteas Supporters Club, after he was selected to audition to be the team's number one fan. The visit was flighted over the various TV platforms and went viral across the globe, generating significant goodwill for the team with almost 300,000 views (almost 700,000 minutes watched). ${ }^{36}$ An online media buying agency was brought in to amplify the online viewership of \#ProteaFire content through a paid media strategy on YouTube, as well as to increase message submission through a remarketing banner campaign.

The project team wanted to create a singular focus across all media for the call to action to submit messages of support for the team. A responsive design campaign microsite was created and hosted within CSA's newly revamped website to support the campaign, central to which was a user-friendly mechanism, which allowed fans to submit their messages of support to the Proteas in their preferred language. The site carried the \#ProteaFire branding and selected video content. A back end management system was created to review and filter all messages according to specific criteria, the chosen messages were submitted to CSA weekly and the moderation process continued. A shortlist of 50 messages from a pool of 17,985 was provided to the Proteas team to select their two favorites. ${ }^{37}$

Cricket broadcasts were also instrumental in amplifying the campaign, with commentators briefed on \#ProteaFire including this in their lexicon. Campaign material was used as fillers both on SABC and SuperSport, which was supported by the players doing interviews in the week of each West Indies match. The editorial benefit of this was noticeable as more radio stations, unprompted, started to pick up on \#ProteaFire. ${ }^{38}$ Regional and local radio stations were also used, and timings and stations were aligned to the same time that Proteas were playing in that region. A two-fold approach was used for the radio campaign - generic radio ads were flighted promoting the competition and calling for messages of support; and audience interaction and non-traditional promotions were used to engage with listeners around \#ProteaFire with prize giveaways and player interviews. ${ }^{39}$

\footnotetext{
${ }^{35}$ Ibid.

${ }^{36}$ Ibid.

${ }^{37}$ Ibid.

${ }^{38}$ Ibid.

${ }^{39}$ Ibid.
} 
A daily social media content plan was created to support the call to action for messages of support - this communication informed fans of where to enter, shared examples of messages that were being sent through, and highlighted the prize of an opportunity to be with the team in Australia during the CWC. ${ }^{40}$ The stadiums also played an important role, with \#ProteaFire branding being manufactured to support the campaign, including flags, fence scrims, player balcony banners, team room and dressing room decor. Messages from fans and the ongoing call to action to enter the competition were played on the big screen and LEDs, and a \#ProteaFire banner competition was held. ${ }^{41}$ A highly-anticipated cricket match between the Proteas and the national rugby team, the Springboks, was used to garner messages of support from the Springboks, which were played on the big screen and LEDs in the stadium. ${ }^{42}$

The team announcement was a key event held at the V\&A Waterfront entertainment complex in Cape Town, which was preempted by a team photo shoot with the iconic Table Mountain in the background, and was followed by a signing session. Another significant highlight of the campaign was the team sendoff, which was held at the Melrose Arch Piazza entertainment complex in Johannesburg on 4 February. Social media was a key tool to drive awareness for the send-off, as was Lead $\mathrm{SA}^{43}$ which promoted the event on radio and their social media platforms. This aspect of the \#ProteaFire campaign began on 27 January when a press release was issued encouraging fans to get behind the team. Over 7,000 fans turned up on the day to show their support, with many arriving long before the scheduled start. The event was also attended by the national government Minister of Sport, Fikile Mbalula, members of his department and the winners of the CSA Inspire \#ProteaFire competition. In turn, sponsors amplified the campaign and pushed \#ProteaFire across their platforms. ${ }^{44}$

\section{Phase 3 - It's Cricket World Cup time!}

Phase 3 continued to build on the messaging 'South Africa you inspire \#ProteaFire'. Ensuring that the team knew they had the support of South Africans during the CWC was a key focus in this phase. It was also important to maintain the campaign's momentum; with Australia and New Zealand being in different time zones to South Africa, it was important to ensure there was not a case of 'out of sight, out of mind'. ${ }^{45}$

A daily social media content plan was again created, which reinforced the qualities of \#ProteaFire; it was important for the public to know not only about winning but also bouncing back, not blaming each other, and living Protea Fire on and off the field. SuperSport and the SABC continued to flight the 'This is \#ProteaFire' TV content, keeping the essence of Protea Fire burning in South Africa. ${ }^{46}$ Thirteen tour diaries were created during the World Cup, which were hosted on CSA's YouTube channel and shared with the SABC, SuperSport, Star TV and Facebook. These gave fans behind the scenes access to the change room and team practices, which they would otherwise never have had. ${ }^{47}$

Of the mediums used during the campaign, Twitter was the one that the players liked best; along with Instagram, it allowed them to share their true feelings in real time and thank the fans for their messages of

\footnotetext{
${ }^{40}$ Ibid.

${ }^{41}$ Ibid.

42 Ibid.

${ }^{43}$ Lead SA is a Primedia Broadcasting initiative, supported by Independent Newspapers, that aims to encourage South Africans to stand up and be a leader

${ }^{44}$ Final report by Lynn Naude, 28 May 2015

${ }^{45}$ Final report by Lynn Naude, 28 May 2015

${ }^{46}$ Ibid.

${ }^{47}$ Final report by Sipokazi Sokanyile, 8 June 2015
} 
support. The Proteas were rated one of the most Twitter-friendly teams in the World Cup, with 12 of the 15 players being active on the platform. ${ }^{48}$

\#ProteaFire Fridays were introduced by CSA in partnership with Lead SA to rally South Africans behind the Proteas and to show their support by wearing their green and gold every Friday. A post to remind fans to wear their shirts on Fridays went out every Tuesday, with two reminder posts on Thursdays. In the same vein, a post with the broadcast details of each match went out every day, with results put up the following day to generate more conversation. Images of campaign quotes and players were used throughout the campaign, while the \#ProteaFire TV commercials were also used to create hype before matches. $^{49}$

As the Proteas moved closer to the quarter finals in March 2015, the campaign began including the name of the city where the next match would be held in order to gain the support of South Africans living there, for example 'Sydney, you inspire \#ProteaFire'. The intention was also to capture fans whose "'first team", had possibly been knocked out to "adopt" the Proteas as a team. A special 'shirt of messages' was created for each team member which carried messages of support from family members, fans and inspirational South Africans such as John Smit, Archbishop Tutu and Ernie Els, while the match day shirts of all the members of the World Cup squad had a phrase from the team song printed on the inside and on their team numbers. ${ }^{50}$

Finally, a familiar 'home away from home' environment was created in the change rooms, with the \#ProteaFire look and feel carried through on the walls and spaces. Campaign images, fan messages and highlights of South African history were all used to create the changing room branding. A message of support from South Africa to the team was also created for the semi-final vs New Zealand, which was used on TV and in social media. ${ }^{51}$

\section{Campaign metrics}

While the campaign had many different facets it was very budget driven, so the project team had to prioritize and use their partnerships to get the best value possible out of the various components. Lynn and her team wanted to be in as many places as they could in all the phases, but they were aware that "when you're trying to mobilize South Africans it's difficult to say who your target audience is - no-one has a big enough budget to target the whole country, so we had to keep prioritizing and saying "What do we have that we can utilize?",52 According to Naude: "The results speak for themselves. Just utilizing the total media value of R51,448,122.00 we generated an overall ROI of $1: 5^{53}$. This excludes the brand affinity, growth on social media platforms, sentiment or brand engagement metrics. ${ }^{, 54}$ The media value included TV and radio advertising exposure of R20,6m and $\mathrm{R} 7.7 \mathrm{~m}$ respectively, which was reported as delivering an ROI of 1:4 and 1:5 each. With the \#ProteaFire content employed by the SABC and SuperSport as unpaid for cricket broadcast 'filler content', Naude commented that this generated an additional $\mathrm{R} 16,5 \mathrm{~m}$ TV advertising value. The total media value also included $\mathrm{R} 6.7 \mathrm{~m}$ in print and broadcast editorial value.

\footnotetext{
${ }^{48}$ Ibid.

${ }^{49}$ Ibid.

${ }^{50}$ Ibid.

${ }^{51}$ Ibid.

${ }^{52}$ Ibid.

${ }_{54}^{53}$ In early 2015,1 US $\$=$ R 12

${ }^{54}$ Ibid.
} 
According to Facebook Insights, the CSA Facebook page received 174,423 likes between 28 January 2015 and 25 March 2015 to reach 2,024,462 likes. In the six month period leading up to the end of the World Cup, subscriptions to the YouTube channel trebled, with 341,000 views during the six week period of the World Cup alone and over $1 \mathrm{~m}$ views (over $2 \mathrm{~m}$ minutes watched) during the entire campaign. ${ }^{55}$ Twitter Analytics for the month of March saw over 63,000 new followers (378,000 extrapolated across the campaign period), with in excess of 230,000 profile visits, almost 50,000 @OfficialCSA mentions and 19.1 million tweet impressions. ${ }^{56}$ The remarketing campaign delivered an audience database of 480,000 people in six weeks, with 7,716 click-throughs from 31 unique banner adverts to the message submission page.

Naude explained that a significant portion of the budget had been spent on content creation, but "there's no point having amazing content if you can't amplify it. The Proteas were open to creating content that authentically showed themselves to the public in a way that few professional sportspeople do. We had some great partners who helped us to better understand that world and put some useful targets in place for us. If I look back at some of the successes of the videos we shot, I can see how the money we put into them reaped rewards, either through our amplification strategy or organically. We found social media to be a very attractive and friendly marketing tool to get our message out; a little bit of advertising spend on social media reaps rewards." ${ }^{, 57}$

In order to test awareness of the campaign and gauge the impact on the affinity/love for the Proteas brand, a research report was commissioned from Repucom, which found that TV was by far the biggest driver of awareness of the campaign at $82 \%$. When it came to the meaning of \#ProteaFire, the feedback was very positive in that fans saw \#ProteaFire as more than winning; what resonated most was that it represents a culture of working as a team. Resilience, diversity and unity also scored high and there was a $10 \%$ increase in the number of respondents who were now a 'supporter of the Proteas'. 'Pride' also increased by $10 \% .^{58}$

Some of the respondents' comments included:

- "It was out of this world and just felt there is much we can do if we are united"

- "Fell even more in love with them"

- "Even prouder if that is possible". 59

Almost all respondents (91\%) agreed or strongly agreed that "they are very proud that this team represents them", while $60 \%$ said they were more likely to attend more Proteas cricket matches than before, and $43 \%$ said they were more likely to attend more domestic matches than before. The vast majority (92\%) stated that Protea Fire could carry this team through good and bad times. ${ }^{60}$

\section{The last two balls}

With the New Zealand team needing five runs to win, Dale Steyn ran in to bowl the penultimate ball of the CWC semi-final to Grant Elliott. The batsman smashed the ball into the crowd for six runs, sending New Zealand into their first final, and sending the Proteas back home.

\footnotetext{
${ }_{56}^{55}$ Final report by Sipokazi Sokanyile, 8 June 2015

${ }^{56}$ Ibid.

${ }^{57}$ Interview with Lynn Naude, 31 March 2015

${ }^{58}$ Final report by Lynn Naude, 28 May 2015

${ }^{59}$ Ibid.

${ }^{60}$ Final report by Sipokazi Sokanyile, 8 June 2015
} 
Jury, the project team, and the country reeled in disappointment. The next day the CSA team was scheduled to meet to review the status of the \#ProteaFire campaign and consider their plans for the next few weeks. He was committed to the team's authentic Protea Fire concept, which had differentiated this campaign from anything he had seen before, and wondered how captain $\mathrm{AB}$ de Villiers and the team would respond. Jury also wondered how the \#ProteaFire campaign should respond to the loss, as part of the ongoing team-led brand strategy. What messaging would be most appropriate? How should the planned media platforms be used to best communicate during phase four? Jury expected negative responses from some fans, and wondered which fans would respond more negatively than others, and whether different approaches were required for different groups.

Taking a broader view, Jury considered how successful the \#ProteaFire campaign had been thus far. The media value seemed impressive, but Jury wanted to understand how these related to the goals they had set for themselves. Recent research had put the rate of a click, favourite, retweet, or reply on Twitter at $\$ 0.10^{61}$. Jury was pleased to have seen the social media amplification of their investment in content creation, and wondered whether their balance of paid, owned and earned media had been optimal.

\footnotetext{
${ }^{61}$ Wood, N. T., \& Burkhalter, J. N. (2014). Tweet this, not that: A comparison between brand promotions in microblogging environments using celebrity and company-generated tweets. Journal of Marketing Communications, 20(1-2), 129-146.
} 
EXHIBIT 1: Proteas One-Day International Cricket Performance ${ }^{62}$

\begin{tabular}{|l|l|}
\hline Cricket World Cup & Performance \\
\hline & \\
\hline 1975 & Did not play \\
\hline 1979 & Did not play \\
\hline 1983 & Did not play \\
\hline 1987 & Did not play \\
\hline 1992 & Semi Finals loss \\
\hline 1996 & Quarter Finals loss \\
\hline 1999 & Semi Finals loss \\
\hline 2003 & Group stage loss \\
\hline 2007 & Semi Finals loss \\
\hline 2011 & Quarter Finals loss \\
\hline & \\
\hline 2015 Internationals (before World Cup) & Performance \\
\hline & \\
\hline Versus West Indies in Durban & Win \\
\hline Versus West Indies in Johannesburg & Win \\
\hline Versus West Indies in East London & Win \\
\hline Versus West Indies in Port Elizabeth & Loss \\
\hline Versus West Indies in Centurion & Win \\
\hline & \\
\hline 2014 Internationals & Performance \\
\hline & \\
\hline Versus Sri Lanka in Colombo & Win \\
\hline Versus Sri Lanka in Pallekele & Loss \\
\hline Versus Sri Lanka in Hambantota & Win \\
\hline Versus Zimbabwe in Bulawayo & Win \\
\hline Versus Zimbabwe in Bulawayo & Win \\
\hline Versus Zimbabwe in Bulawayo & Win \\
\hline Versus Australia in Harare & Win \\
\hline Versus Zimbabwe in Harare & Win \\
\hline Versus Australia in Harare & Loss \\
\hline Versus Zimbabwe in Harare & Win \\
\hline Versus Australia in Harare & Win \\
\hline Versus New Zealand in Mount Maunganui & Win \\
\hline Versus New Zealand in Mount Maunganui & Win \\
\hline Versus New Zealand in Hamilton & No result \\
\hline Versus Australia in Perth & Loss \\
\hline Versus Australia in Perth & Win \\
\hline Versus Australia in Canberra & Loss \\
\hline Versus Australia in Melbourne & \\
\hline Versus Australia in Sydney & Loss \\
\hline
\end{tabular}

${ }^{62}$ Source: Brand South Africa, http://www.southafrica.info/about/sport/cricket.htm\#.WAZmjZMrKRs; and ESPNcricinfo, http://stats.espncricinfo.com/ci/engine/records/team/match_results.html?class=2;id=2014;team=3;type=year 
EXHIBIT 2: Selection of creative visuals for campaign
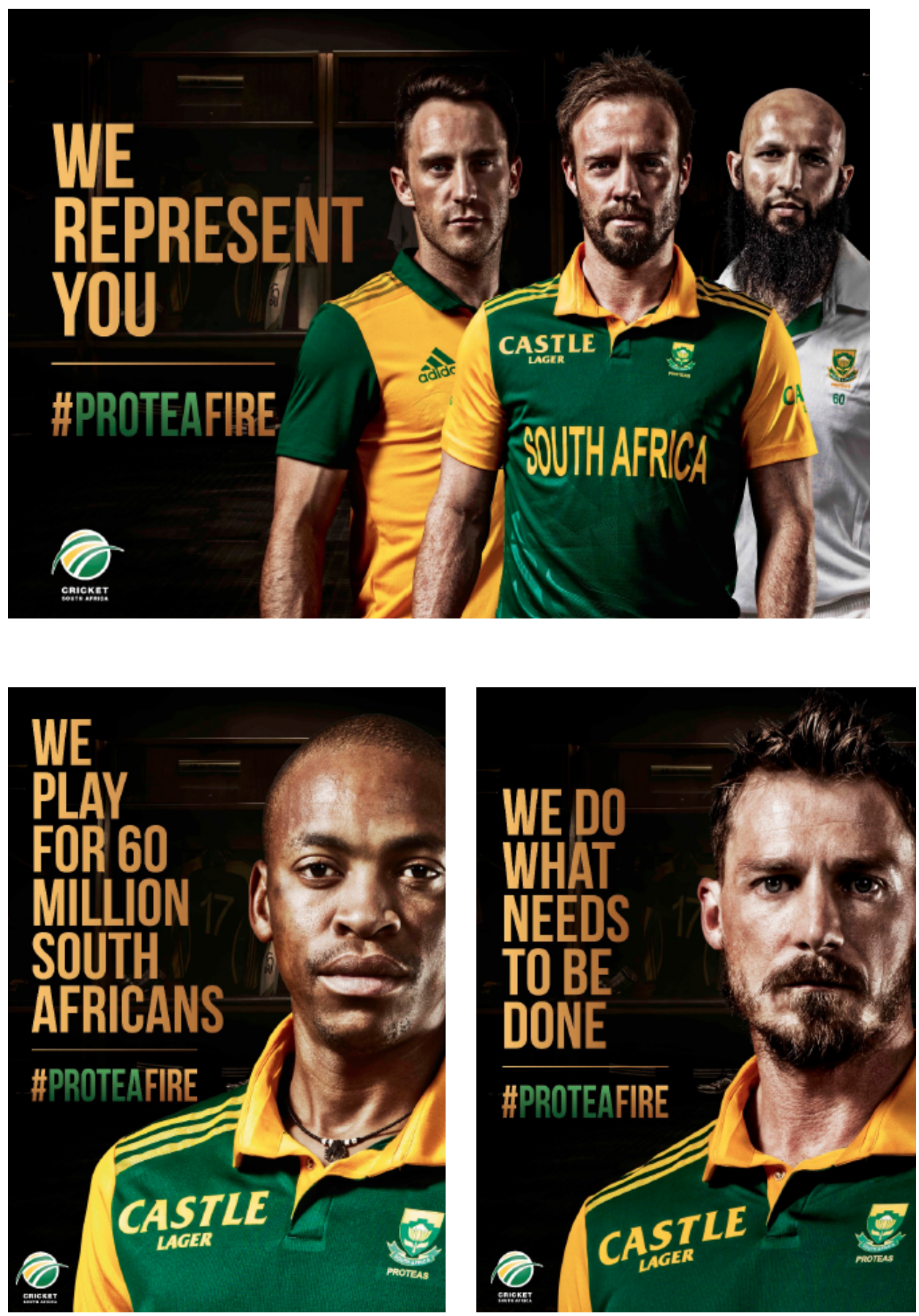